\title{
Correction to: Expected Budget Impact and Health Outcomes of Expanded Use of Vagus Nerve Stimulation Therapy for Drug-Resistant Epilepsy
}

\author{
Molly F. Purser · Deirdre M. Mladsi · Alan Beckman · Francesca Barion · \\ John Forsey
}

Published online: September 12, 2018

(C) The Author(s) 2018

Correction to: Adv Ther

https://doi.org/10.1007/s12325-018-0775-0

The article "Expected Budget Impact and Health Outcomes of Expanded Use of Vagus Nerve Stimulation Therapy for Drug-Resistant Epilepsy", written by Molly F. Purser, Deirdre M. Mladsi, Alan Beckman, Francesca Barion, John Forsey was originally published electronically on the publisher's internet portal (currently SpringerLink) on August 24, 2018 without open access.

The original article can be found online at https://doi. org/10.1007/s12325-018-0775-0.

M. F. Purser $(\varangle)$. D. M. Mladsi

The copyright of the article changed to (C) The Author(s) 2018 and the article is forthwith distributed under the terms of the Creative Commons Attribution-NonCommercial 4.0 International License (http://creativecommons. org/licenses/by-nc/4.0/), which permits any non-commercial use, distribution, and reproduction in any medium, provided you give appropriate credit to the original author(s) and the source, provide a link to the Creative Commons license, and Indicate if changes were made.

The original article has been updated.

Open Access. This article is distributed under the terms of the Creative Commons Attribution-NonCommercial 4.0 International License (http://creativecommons.org/licenses/ by-nc/4.0/), which permits any noncommercial use, distribution, and reproduction in any medium, provided you give appropriate credit to the original author(s) and the source, provide a link to the Creative Commons license, and indicate if changes were made.

RTI Health Solutions, Research Triangle Park, NC,

USA

e-mail: mpurser@rti.org

A. Beckman

LivaNova USA, Inc., Houston, TX, USA

F. Barion · J. Forsey

LivaNova PLC, London, UK 